\title{
AGAMA DAN INTERAKSI SOSIAL: Potret Harmoni Beragama Di Wiyono Kabupaten Pesawaran
}

\section{Suhandi}

Universitas Islam Negeri RadenIntan Lampung

subandi@radenintan.ac.id

\section{Abstract}

In their capacity as social beings, bumans tend to relate and interact with their environment. Social interactions are always preceded by a social contact and communication. This contact is then continued with associative or dissociative or oppositional processes. The associative process begins with cooperation then continues with accommodation, assimilation and acculturation. This study focuses on efforts to portray the harmony of religious communities in the Wiyoni area of Pesawaran District. From the results of the study it can be concluded that: Social interactions that occur are more directed to dynamic interactions where the occurrence of two-way interactions that are mutually beneficial that gives birth to associative interactions that is mutually reinforcing. So that this leads to the realization of harmonization in life between religious communities. While the factors that support the interaction are mutual respect between religions with one another (Islam and Christianity), support from religious leaders, and ethnically in the village Wiyono is predominantly a Javanese population who prioritizes a culture of mutual respect with one another.

\section{Abstrak}

Dalam kapasitasnya sebagai makbluk sosial, manusia cenderung berbubungan dan melakukan interaksi dengan lingkungannya.Adapun interaksi sosial selalu didabului oleh suatu kontak sosial dan komunikasi. Kontak ini kemudian dilanjutkan dengan proses-proses yang asosiatif ataupun yang disasosiatif atau oposisional. Proses asosiatif dimulai dengan kerja sama kemudian dilanjutkan 
dengan akomodasi, asimilasi, dan akulturasi. Penelitian ini memfokuskan pada upaya memotret harmonisasi masyarakat beragama di daerah Wiyoni Kabupaten Pesawaran. Dari Hasil penelitian dapat disimpulan bahwa: Interaksi sosial yang tejadi lebih mengarah pada interaksi yang dinamis dimana terjadinya interaksi dua arah yang saling menguntungkan yang melahirnya interaksi assosiatif yakni saling menguatkan. Sehingga hal yang demikian mengarah pada terwujudnya harmonisasi dalam kehidupan antar umat beragama.Sedangkan faktor yang mendukung terjadinya interaksi adalah adanya saling menghormati antara agama yang satu dengan yang lain (Islam dan Kristen), adanya dukungan dari tokohtokoh agama, dan secara etnis di desa Wiyono sebagian besar berpenduduk Jawa yang secara budaya lebih mengedepankan budaya saling menghoremati dengan sesama.

Keywords: Religion, Social Interaction, Religious Harmony, Wiyono

\section{A. Pendahuluan}

Keinginan setiap agama dan manusia itu sendiri adalah hidup rukun, saling menghormati dan menghargai ini meruapakan bagian dari Pluralisme agama.Pluralisme adalah kondisi hidup bersama antar umat beragama dalam satu komunitas dengan tetap mempertahankan ciri-ciri spesifik dari ajaran masing-masing agama. ${ }^{1}$ Pluralitas agama merupakan sebuah rahmat serta anugerah yang terindah dan patut kita syukuri, akan tetapi sekaligus merupakan sebuah tantangan ${ }^{2}$ bagi umat itu sendiri. Karena dalam realitasnya keberadaan akan adanya pluralitas agama ini terkadang menjadi syarat dengan adanya kepentingan.

Interaksi sosial merupakan kunci dari semua kehidupan sosial.Tanpa interaksi sosial, tidak mungkin ada kehidupan bersama. ${ }^{3}$ Dalam kapasitasnya sebagai makhluk sosial, manusia cenderung berhubungan atau berinteraksi dengan lingkungannya.Adapun interaksi sosial selalu didahului oleh suatu kontak sosial dan

${ }^{1}$ Anis Malik Thoha, Tren Pluralisme Agama: Tinjanan Kritis, cet ke 2 (Jakarta : Perspektif Kelompok Gama Insani, 2006), h. 14.

${ }^{2}$ A.A. Yewangoe, Agama dan Kerukunan( Jakarta : PT Gunung Mulia, 2002),h. 22.

${ }^{3}$ Zainal Abidin dan Ahmad Safe'i, Sosiosophologi ; Sosiologi Islam Berbasis Hikmah(Bandung : CV Pustaka Setia, 2003), h. 107. 
komunikasi. ${ }^{4}$ Kontak ini kemudian dilanjutkan dengan proses-proses yang asosiatif ataupun yang disasosiatif atau oposisional. Proses asosiatif dimulai dengan kerja sama kemudian dilanjutkan dengan akomodasi, asimilasi, dan akulturasi. Masing-masing subsistem sosial ini saling berinteraksi atau kontak sehingga menimbulkan bentukbentuk yang mengarah pada integrasi, termasuk solidaritas sosial atau dapat pula menciptakan kondisi kehidupan yang sebagian pada disintegrasi, konflik dan harmonis pada tatanan sosial. ${ }^{5}$

Masyarakat desa Wiyono adalah suatu daerah yang terletak di wilayah kabupaten Pesawaran. Masyarakat beragama di desa ini hidup dengan rukun dan damai; hidup berdampingan, saling membantu, saling menghargai, saling menghormati, dan saling memahami antara penganut agama yang satu dengan agama yang lain. Penduduk desa Wiyono sebagian besar beragama Islam sekitar $70 \%$ dan yang lainnya Bergama Kristen sekitar $30 \%$.Dilhat dari sisi kehidupan soSial kehidupan mereka menampil suatu fenomena yang menarik; karena mereka meskipun berbeda agama namun satu dengan yang lainnya dapat hidup secara harmonis, tanpa ada kebencian, pertengkaran, saling memojokkan, namun mereka hidup rukun dan salin menolong.

Kondisi ini perlu diteliti lebih jauh tentang berbagai faktor yang mendukung terjadinya suatu proses interaksi yang dinamis dalam kehidupan bermasyarakat, dan sejauhmana hal ini berpengaruh pada harmonisasi kehidupan beragama mereka.

\section{B. Interaksi Sosial}

\section{a. Pengertian Interaksi Sosial}

Para pakar banya mengemukakan tentang pengertian Interaksi Sosial yang berbeda-beda meskipun banyak kesamaan yang dikemukakan, sehingga akan tergambar secara global pemahaman kita tentang interaksi sosial yang sesungguhnya. Untuk itu di bawah ini akan dikemukakan beberapa definisi yang dikemukakan oleh para pakar sosiologi.

${ }^{4}$ Ibid.,

${ }^{5}$ Fauzi Fatah, Solidaritas Sosial Keagamaan dalam Masyarakat Perkotaan (Bandar Lampung : IAIN Raden Intan Lampung, 1995), h. 63. 
Pengertian Interaksi Sosial Menurut John Lewis Gillin Interaksi sosial merupakan hubungan-hubungan sosial dinamis yang menyangkut hubungan antarindividu, antara individu dan kelompok, atau antarkelompok yang satu dengan kelompok yang lainnya. Pengertian ini menunjukkan adanya suatu proses yang dinamis yang terjadi dalam semua komponen kehidupan masyarakat. Sedangkan Homans mendefinisikan interaksi sebagai suatu kejadian ketika suatu aktivitas yang dilakukan oleh seseorang terhadap individu lain diberi ganjaran atau hukuman dengan menggunakan suatu tindakan oleh individu lain yang menjadi pasangannya. ${ }^{6}$ Konsep yang dikemukakan oleh Homans ini mengandung pengertian bahwa interaksi adalah suatu tindakan yang dilakukan oleh seseorang dalam interaksi merupakan suatu stimulus bagi tindakan individu lain yang menjadi pasangannya. ${ }^{7}$ Jadi Homnas melihat interaksi adalah merupakan tindakan individu dan bukan kelompok kepada individu yang lainnya sebagai respons sikap seseorang terhadap perilaku seseorang terhadap dirinya. Tokoh ketiga yang dikemukakan pada bagia ini adalah Bonner yang memberikan pengertian Interaksi sosial menurut sebgai suatu hubungan antara dua orang atau lebih individu, dimana kelakuan individu mempengaruhi, mengubah atau mempengaruhi individu lain atau sebaliknya.

Dari tiga definisi yang dikemukakan di atas, maka dapat difahami secara umum, bahwa interaksi sosial adalah adanya hubungan timbal balik antara dua orang atau lebih dan masingmasing orang yang terlibat di dalamnya memainkan peran secara aktif.

\section{b. Ciri-Ciri Interaksi Sosial}

Menurut Muhamamd Basrowi dan Soenyono ada empat ciri ciri interaksi sosial, antara lain :

1. Adanya pelaku dengan jumlah lebih dari satu orang.

'J.B. Banawiratman dan Franz Magniz-Suseno, "Dinamika Kerukunan Umat Beragama Di Indonesia Tinjauan Kristen Katholik", dalam Mursyid Ali, Dinamika Kerukunan Hidup Beragama Menurut Perspektif Agama-Agama Bingkai Teologi KerukunanHidup Beragama (Jakarta: Badan Penelitian Pengembangan Agama Proyek PeningkatanKerukunan Hidup Umat Beragama, 2000), h. 87.

${ }^{7}$ Ibid. 
2. Adanya komunkasi antar pelaku dengan menggunakan symbol-simbol.

3. Adanya dimensi waktu (masa lampau, masa kin, dan masa mendatang) yang menentukan sifat aksi yang sedang berlangsung.

4. Adanya tujuan-tujuan tertentu, terlepas dari sama atau tidaknya tujuan tersebut, dengan yang dioerkirakan oleh pengamat. ${ }^{8}$

Sementara Soejono Soekanto hanya mengisyaratkan dua hal :

1. Adanya kontak sosial (social-contact)

2. Adanya komunikasi. ${ }^{9}$

Syarat-syarakat dalam interaksi sosial di atas menunjukkan bahwa dalam proses interaksi yang terjadi dalam kehidupan masyarakat meskipun terjadi secara alami dalam kehidupan sosial, tetapi dalam konteks ilmu sosial ada indikator yang harus terpenuhi sebagai bentuk terjadinya proses interaksi dalam kehidupan masyarakat. Indikator yang dimaksudkan paling tidak adanya kontak social dan komunikasi pada saat berlangsungnya interaksi.

Kontak sosial adalah hubungan antara satu orang atau lebih, melalui percakapan dengan saling mengerti tentang maksud dan tujuan masing-masing dalam kehidupan masyarakat. ${ }^{10}$ Sehingga kontak sosial yang berlangsung ada yang terjadi secara langsung; yakni terjadi pertemuan secara fisik antara satu orang atau lebih dalam situasi tertentu. Sedangkan yang secara tidak langsung terjadi lewat media tertentu, misalnya dengan menggunakan alat komunikasi, radio, surat atau alat yang lainnya.

Sedangkan komunikasi sosial mengandung pengertian adanya persamaan pandangan antara orang-oarng yang berinteraksi terhadap sesuatu. ${ }^{11}$ Dengan adanya komunikasi, maka sikap dan perasaan di satu pihak orang atau kelompok orang dapat diketahui dan dipahami oleh pihak orang atau kelompok orang lain.

8 Muhammad Basrowi \& Soenyono, Memahami Sosiologi, (Surabaya: Lutfansah Mediatama, 2004), h. 172-173.

${ }^{9}$ Soejono Soekanto, Op.Cit. h. 58

${ }^{10}$ Muhammad Basrowi \& Soenyono, Op.Cit.h. 154

${ }^{11}$ Ibid. h. 155 


\section{c. Faktor-Faktor Yang Mempengruhi}

Sebagai suatu perilaku, maka interaksi sosial tidak muncul dengan sendirinya namun ada beberapa faktor yang mempengaruhi berlangsungnya suatu proses interaksi. Ada beberapa hal yang dapat mempengaruhi interaksi social yang terjadi dalam kehidupan madyarakat, antara lain :.

\section{Imitasi}

Imitasi adalah suatu proses belajar dengan cara meniru atau mengikuti perilaku orang lain. ${ }^{12}$ tindakan atau usaha untuk meniru tindakan orang lain yang dianggap sebagai orang atau tokoh idealnya atau yang dikaguminya. Imitasi cenderung secara tidak disadari dilakukan oleh seseorang. Imitasi pertama kali akan terjadi dalam sosialisasi keluarga.

\section{Sugesti}

Sugesti adalah pengeruh-pengaruh yang diberikan oleh seseorang atau sekelompok orang kepada seseorang atau sekelompok orang sehingga orang yang mendapatkan sugesti akan menuruti apa yang menjadi keinginan dari si pemberi sugesti tanpa pertimbanganpertimbangan yang bersifat rasional. ${ }^{13}$ Yakni pemberian pengaruh pandangan seseorang kepada orang lain dengan cara tertentu sehingga orang tersebut mengikuti dan terpengaruh oleh pandangan tersebut tanpa berpikir panjang.

\section{Identifikasi}

Identifikasi adalah kecenderungan atau keinginan dalam diri seseorang untuk menjadi sama dengan orang lain, yakni sesorang berupaya menjadi seperti orang lain. ${ }^{14}$ Identifikasi mengakibatkan terjadinya pengaruh yang lebih dalam dari sugesti dan imitasi karena identifikasi dilakukan oleh seseorang secara sadar.

4. Simpati

12 Muhammad Basrowi \& Soenyono, Op.Cit.h. 178

13 Agung Triharyanto \& Eko Sujatmiko, Kamus Sosiologi, (Surakarta: PT. Aksarra Sinergi Media, 2012), h.249.

14 J.B.A.F. Maijor Polak, Sosiologi: Suatu Buku Pengatntar Ringkas, (Jakarta: Ichtiar Baru - Van Hove, 1985), h. 98. 
Simpati adalah suatu kecakapan untuk merasakan diri solaholah dalam keadaan orang lain dan ikut merasakan apa yang dilakukan, dialami, atau diderita oleh orang lain. ${ }^{15}$ Yakni suatu proses seseorang yang mampu merasakan sesuatu yang dialami pada orang lain. Perasaan simpati itu bisa juga disampaikan kepada seseorang atau sekelompok orang atau suatu lembaga formal pada saat-saat khusus.

\section{Empati}

Empati adalah kemampuan mengambil atau memainkan peranan secara efektif dan seseorang atau orang lain dalam konsidi yang sebenar-benarnya, seolah-olah ikut merasakan apa yang dirasakan oleh orang lain tersebut seperti rasa senang, sakit, susah, dan bahagia. ${ }^{16}$ Empati hampir mirip dengan sikap simpati.Perbedaannya, sikap empati lebih menjiwai atau lebih terlihat secara emosional.

\section{Motivasi}

Motivasi adalah dorongan-dorongan, baik yang datang dari dalam maupun luar individu sehingga dapat menggerakkan individu untuk berbuat atau melakukan sesuatu. Dorongan-dorongan inilah yang akan membentuk kepribadian individu sebagai warna dalam kehidupan bermasyarakat. ${ }^{17}$ rangsangan, pengaruh, atau stimulus yang diberikan seorang individu kepada individu yang lain sedemikian rupa sehingga orang yang diberi motivasi tersebut menuruti atau melaksanakan apa yang dimotivasikan secara kritis, rasional, dan penuh tanggung jawab.

\section{d. Syarat- Syarakat Interaksi Sosial}

Menurut Soerjono Soekanto, interaksi sosial tidak mungkin terjadi tanpa adanya dua syarat, yaitu kontak sosial dan komunikasi.

\section{Kontak Sosial}

Kata "kontak" (contact) berasal dari bahasalatincon atau cum yang artinya bersama-sama dan tangere yang artinya menyentuh. Jadi, kontak berarti bersama-sama menyentuh. Kontak sosial adalah

\footnotetext{
${ }^{15}$ Ibid. h. 97

16 Agung Triharyanto \& Eko Sujatmiko, Op.Cit.h. 58

${ }^{17}$ Ibnid., h. 156
} 
hubungan masing-masing pihak dalam berinteraksi orang dengan perorangan, perorangan dengan kelompok, kelompok dengan kelompok. Sehingga kontak social dijelaskan bukan semata-mata tergantung dari tindakan, tetapi juga akan tergantung pada adanya tanggapan terhadap tindakan tersebut. ${ }^{18}$

\section{Komunikasi}

Komunikasi adalah suatu proses saling memberikan tafsiran kepada atau dari perilaku pihak lain. Sehingga melalui tafsiran pada perilaku pihak lain, seseorang mewujudkan perilaku tertentu sebagai reaksi terhadap maksud atau peran yang ingin disampaikan oleh pihak lain itu. ${ }^{19}$ Sementara Soejono Soekanto mengartikan komunikasi sebagai sikap seseorang dalam upaya memberi arti pada perilaku orang lain, perasaan-perasaan apa yang ingin disampaikan oleh orang tersebut. ${ }^{20}$ Proses seperti ini berlangsung secara alami dalam kehidupan individu dan masayarakat.

\section{e. Bentuk-Bentuk Interaksi Sosial}

Interaksi sosial mempunyai dua bentuk, yakni interaksi sosial yang mengarah pada bentuk penyatuan (proses asosiatif) dan mengarah pada bentuk perpecahan (proses disosiatif).

\section{a. Proses Asosiasi}

Interaksi sosial asosiatif adalah pola hubungan yang menunjukkan kerja sama, proses sosial yang di dalamnya ada usaha dan upaya untuk menyatukan dan meningkatkan solideritas di antara anggota kelompok. ${ }^{21}$ Dengan demikian asosiatif merupakan bentuk interaksi sosial yang menghasilkan kerja sama, sesama inidividu atau kelompok terjalinnya kebersamaan dalam kondisi dan situasi tertentu. Ada beberapa bentuk interaksi sosial asosiatif, antara lain sebagai berikut :

a) Kerjasama (Cooperation)

18 J. Dwi Narwoko \& Bagong Suyanto, Sosiologi: Teks Pengantar dan Terapan, (Jakarta: Prenada Media Grup, 16), 2004,h. 16

${ }^{19}$ Muhammad Basrowi \& Soenyono, Op.Cit.h. 56.

20 Soejono Soekanto, Op.Cit. h. 62

21 Agung Triharyanto \& Eko Sujatmiko, Op.Cit.h. 16 
Kerja sama adalah suatu bentuk proses sosial dimana di dalamnya terdapat aktivitas tertentu yang ditujukan untuk mncapai tujuan bersama dengan saling membantu dan saling memahami terhadap aktivitas masing-masing. ${ }^{22}$ Dengan demikian, kerja sama timbul apabila orang menyadari bahwa mereka mempunyai kepentingan-kepentingan yang sama dan pada saat yang bersamaan mempunyai cukup pengetahuan dan pengendalian terhadap diri sendiri untuk memenuhi kepentingan-kepentingan tersebut.,

Ada beberapa bentuk interaksi sosial yang berupa kerja sama, antara lain adalah :

1) Bargaining adalah pelaksanaan perjanjian mengenai pertukaran barang-barang atau jasa antara dua organisasi atau lebih.

2) Cooptation (kooptasi) adalah suatu proses penerimaan unsur-unsur baru dalam kepemimpinan atau pelaksanaan politik dalam suatu organisasi untuk menghindari kegoncangan dalam stabilitas organisasi yang bersangkutan.

3) Coalition (koalisi) adalah kerja sama yang dilaksanakan oleh dua organisasi atau lebih yang mempunyai tujuan yang sama. Koalisi dapat menghasilkan keadaan yang tidak stabil untuk sementara waktu, karena dua organisasi atau lebih tersebut mungkin mempunyai struktur yang berbeda satu sama lain. ${ }^{23}$

b) Akomodasi (Accomodation)

Akomodasi adalah suatu suatu keadaan hubungan antara kedua belah pihak yang menunjukkan keseimbangan yang berhubungan dengan nilai dan norma-norma sosial yang berlaku dalam masyarakat. ${ }^{24}$ Bentuk-bentuk akomodasi adalah sebagai berikut :

1) Coercion(koersi) adalah bentuk akomodasi yang proses pelaksanaannya menggunakan paksaan. Pemaksaan

22 Abdulsyani, Sosiologi Skematika Teori, dan Terapan, (Jakarta: Bimi Aksara, 2012), h. 156.

${ }^{23}$ Ibid. h. 156-157

${ }^{24}$ Ibid. h. 159 
terjadi bila satu pihak menduduki posisi kuat, sedangkan pihak lain dalam posisi lemah.

2) Compromise(kompromi) adalah suatu bentuk akomodasi dimana pihak-pihak yang terlibat saling mengurangi tuntutannya agar tercapai suatu penyelesaian terhadap perselisihan yang ada. Sikap dasar untuk dapat melaksanakan compromise adalah bahwa salah satu pihak bersedia untuk merasakan dan memahami keadaan pihak lainnya dan begitu pula sebaiknya.

3) Arbitration adalah suatu cara untuk mencapai kompromi apabila pihak-pihak yang berhadapan tidak sanggup mencapainya sendiri. Pertentangan diselesaikan oleh pihak ketiga yang dipilih oleh kedua belah pihak atauoleh satu badan yang berkedudukan lebih tinggi dari pihakpihak yang bertentangan.

4) Mediation hampir menyerupai arbitration. Adanya pihak ketiga yang mengusahakan suatupenyelesaian secara damai.Kedudukan pihak ketiga hanyalah sebagai penasehat belaka.

5) Concilation adalah suatu usaha untuk mempertemukan keinginan pihak-pihak yang berselisih demi tercapainya suatu persetujuan bersama.

6) Toleranion juga dinamakan tolerant-participation.Ini merupakan suatu bentuk akomodasi tanpa persetujuan yang formal bentuknya.Dalam bentuk ini terkadang timbul secara tidak sadar dan tanpa direnanakan karena adanya watak orang-perorangan atau kelompokkelompok manusia untuk sedapat mungkin menghindari diri suatu perselisihan.

7) Stalemate adalah suatu akomodasi dimana pihak-pihak yang bertentangan karena mempunyai kekuatan yang seimbang berhenti pada satu titik tertentu dalam melakukan pertentangannya. Hal ini disebabkan karena bagi kedua belah pihak sudah tidak ada kemungkinan lagi baik untuk maju maupun untuk mundur.

8) Ajudication adalah penyelesaian perkara melalui pengadilan. $^{25}$

25 Soejono Soekanto, Op.Cit.h. 70-71. 
9) Asimilasi (assimilation). Asimilasi adalah merupakan proses yang lebih berlanjut apabila dibandingkan dengan proses akomodasi. Pada proses asimilasi terjadi proses peleburan kebudayaan, sehingga pihak-pihak atau wargawarga dari dua atau tiga kelompok yang tengah berasimilasi akan merasakan adanya kebudayaan tunggal yang dirasakan sebagai milik bersama. ${ }^{26}$

10) Amalgamasi. Amalgasi merupakan proses sosial yang melebut dua kelompok budaya menjadi satu, yang pada akhirnya melahirkan sesuatu yang baru. ${ }^{27}$

\section{b. Proses Disosiasi}

Disosiatif adalah proses sosial yang cenderung membawa anggota masyarakat kea rah perpecahan dan merenggangkan solidaritas di antara anggotanya. ${ }^{28}$ jadi disosiatifmerupakan bentuk interaksi sosial yang menghasilkan sebuah perpecahan. Ada beberapa bentuk interaksi sosial disosiatif, antara lain sebagai berikut:

\section{a) Persaingan (competition)}

Persaingan dapat diartikan sebagai sutau proses sosial, dimana individu atau kelompok-kelompok manuisa yang bersaing mencari keuntungan memlalui bidang-bidang kehidupan yang pada satu masa tertentu menjadi pusat perthatian umum (baik perseorangan maupun kelompok manusia) dengan cara menarik perhatian publik atau dengan mempertajam prasangka yang telah ada tanpa mempergunakan ancaman atau kekerasan. Persaingan mempunyai dua tipe umum, yakni yang bersifat pribadi dan tdak pribadi.Persaingan yang bersifat pribadi, orang-perorangan, atau individu secara langsung bersaing untuk, misalnya memperoleh kedudukan tertentu di dalam suatu organisasi.Sedangkan persaingan yang tidak bersifat pribadi, yang bersaing adalah kelompok.Persaingan misalnya dapat terjadi antara dua

\footnotetext{
${ }^{26}$ J. Dwi Narwoko \& BagongSuyanto, Op.Cit. h. 62

${ }^{27}$ Ibid., .h 64

28 Agung Triharyanto \& Eko Sujatmiko, Op.Cit.h. 52.
} 
perusahaan besar yang bersaing untuk mendapatkan monopoli di suatu wilayah. ${ }^{29}$

b) Kontravensi (contravention)

Kontraversi berasal dari bahasa lain, dari kata conta dan venire, yang berarti menghalangi atau menantang. ${ }^{30}$ Kontravensi pada hakikatnya adalah suatu bentuk proses sosial yang berada di antara persaingan dan pertentangan atau pertikaian (konflik). Kontraversi terutama ditandai oleh gejala-gejala adanya ketidakpuasan mengenai diri seseorang atau suatu rencana dan perasaan tidak suka yang disembunyikan, kebencian, atau keragu-raguan terhadap kepribadian seseorang. ${ }^{31}$ Bentuk kontravensi ada 5 yaitu :

1) Kontravensi yang bersifat umum. Seperti penolakan, keengganan, gangguan terhadap pihak lain, pengacauan rencana pihak lain, dan perbuatan kekerasan.

2) Kontravensi yang bersifat sederhana. Seperti memakimaki, menyangkal pihak lain, mencerca, memfitnah, dan menyebarkan surat selebaran.

3) Kontravensi yang bersifat intensif. Seperti penghasutan, penyebaran desas-desus, dan mengecewakan pihak lain.

4) Kontravensi yang bersifat rahasia. Seperti mengumumkan rahasia pihak lain dan berkhianat.

5) Kontravensi yang bersifat taktis. Seperti intimidasi, provokasi, mengejutkan pihak lawan, dan mengganggu atau membingungkan pihak lawan. ${ }^{32}$

c) Konflik

Konflik sebagai suatu proses ternyata dipraktekkan juga secara luasdi dalam masyarakat. Berbeda dengan kompetisi yang selalu berlangsung di dalam suasana "damai", konflik adalah suatu proses sosial yang berlangsung dengan melibatkan orang-orang atau kelompok-kelompok yang saling

\footnotetext{
${ }^{29}$ Soejono Soekanto \& Budi Sulistyowati, Op.Cit.h. 83

${ }^{30}$ J. Dwi Narwoko \& BagongSuyanto, Op.Cit.hlm. 70

${ }^{31}$ Ibid. h. $87-88$

${ }^{32}$ Ibid.
} 
menantang dengan ancaman kekerasan. Dalam bentuknya yang ekstrim, konflik itu berlangsung tidak hanya sekedar untuk mempertahankan hidup dan eksistensi (jadi bersifat defensive), akan tetapi juga bertujuan sampai ke tarap pembinasaan eksistensi orang atau kelompok lain yang dipandang sebagai lawan atau saingannya. ${ }^{33}$

Konflik sebagai suatu proses sosial dapat mengakibatkan munculnya hal-hal yang negative, seperti peperangan, korbankorban akan berjatuhan, hara benda akan hancur berantakan. Namun demikian, konflik juga dapat memunculkan hal-hal yang positif, di antaranya adalah bertambahnya solidaritas intern dan rasa in-group suatu kelompok. Apabila terjadinya pertentangan antar kelompok-kelompok, maka solidaritas antar anggota di dalam masing-masing kelompok akan akan meningkat.

Faktor -faktor penyebab terjadinya konflikadalah :

1) Adanya perbedaan individu yang meliputi perbedaan pendirian dan perasaan.

2) Berprasangka buruk kepada pihak lain

3) Individu kurang bisa mengendalikan emosi

4) Adanya perbedaan kepentingan antara dan kelompok

5) Persaingan yang sangat tajam sehingga kontrol sosial kurang berfungsi.

\section{Harmonisasi Beragama}

\section{a. Pengertian Harmonisasi Beragama}

Ditinjau dari segi etimologi, harmonis berasal dari bahasa Inggris harmonious yang berarti rukun, seia-sekata; harmonious relationship yang berarti hubungan yang rukun; harmonize yang berarti berpadanan, seimbang, cocok, berpadu; harmonis berarti keselarasan, keserasian, kecocokan, kesesuaian, kerukunan. Dalam Kamus Umum Bahasa Indonesia, harmoni adalah keselarasan; selaras.Dalam kamus ilmiah populer diartikan keselarasan, kecocokan, dan keserasian.Ditinjau dari segi terminologi, harmoni adalah keserasian, kehangatan, keterpaduan, dan kerukunan yang

\footnotetext{
${ }^{33}$ Ibid. h. 68.
} 
mendalam dengan sepenuh jiwa melibatkan aspek fisik dan psikis sekaligus.Jadi harmoni yang sebenarnya adalah, jika semua interaksi sosial berjalan secara wajar dan tanpa adanya tekanan-tekanan atau pemaksaan-pemaksaan yang menyumbat jalannya kebebasan. ${ }^{34}$

Dengan demikian harmonis dapat difahami sebagai suatu keadaan masyarakat dimana masyarakat menjalani kehidupannya dengan suasana yang tenteram dan damai baik lahir maupun batin dengan tidak adanya rasa tekanan ataupun keterpaksaan dalam menjalani kehidupannya, shingga kehidupan berjalan dengan aman, nyaman dan tenteram.

\section{b. Bentuk Harmoni}

Pada bagian ini akan dikemukakan beberapa bentuk harmonisasi dlam kehidupan beragama.

1) Dialog Antar Agama

Secara etimologis dialog berarti percakapan atau diskusi antar orang orang yang berbeda pendapat. Dialog sebenarnya berarti "dialeghe" yaitu sedang berbicara, sedang berdiskusi, sedang beralasan mengenai seluruh aspek persoalan, karenanya saling mengoreksi dan bergerak bersama-sama dalam menyelesaikan masalah baru. ${ }^{35}$

Secara terminologis dialog adalah komunikasi dua arah antar orang-orang yang sungguh-sungguh berbeda pandangan terhadap satu subjek dengan tujuan untuk memahami secara lebih baik kebenaran subjek tersebut dari orang lain. Namun demikian, terdapat beberapa rumusan pengertian dan uraian serta pemahaman tentang dialog anta rumat beragama. Misalnya, dialog didefinisikan sebagai pertukaran ide yang diformulasikan dengan cara yang berbeda-beda. Dialog dapat dilukiskan sebagai pertukaran timbal balik dari pandangan-pandangan antara orangorang yang telah memiliki satu kepedulian murni terhadap satu

${ }^{34}$ Josef Van Ess, "Islam dan Barat dalam Dialog", dalam Nurcholish Madjid, dkk., Agama dan Dialog Antar peradaban, (Jakarta: Paramadina, 1996), h. 170.

${ }^{35}$ Ibid. h. 175 
sama lain dan mereka yang terbuka untuk belajar satu sama lainnya. ${ }^{36}$

Dari berbagai pengertian tersebut di atas, dapat dikatakan bahwa dialog agama adalah pertemuan hati dan pikiran antar pemeluk berbagai agama, komunikasi antara orang-orang yang percaya pada tingkat agama, jalan bersama untuk mencapai kebenaran dan kerjasama dalam proyek-proyek yang menyangkut kepentingan bersama, dan merupakan perjumpaan antar pemeluk agama, tanpa merasa rendah dan tanpa merasa tinggi, serta tanpa agenda atau tujuan yang dirahasiakan.

2) Lokakarya Dan Bakti Sosial

Dalam ajang pemersatuan baik secara ideologis maupun secara social masyarakat yang plural perlu menjalin kerjasama dalam hal mempererat cinta kasih antar sesama .jika masyarakat sudah bisa melakukan berbaur dalam hal positif maka akan terjalin rasa persaudaraan yang erat dan akan mustahil terjadinya distorsi terhadap yang lain.

3) Harga Menghargai

Terkadang gerakan-gerakan yang mengatasnamakan agama bisa menimbulakan disubordinasi agama yang lain khususnya gerakan radikalisme agama. Harga menghargai adalah harga yang tidak bias ditawar lagi untuk mempersatukan masyarakat yang plural.Saling harga menghargai dalam kehidupan beragama merupakan hal yang paling perlu diwujudkan mengingat masyarakat Indonesia termasuk paling plural di dunia.Sehingga demi mewujudkan itu semua perlu dilakukan dengan hati yang terbuka agar terwujud kehidupan yang saling harga menghargai.

36A. Mukti Ali, "Agama, Moralitas dan Perkembangan Kontemporer" dalam Mukti Ali, dkk, Agama dalam Pergumulan Masyarakat Dunia, (Yogyakarta: Tiara wacana: 1997), h. 7. Lihat juga dalam W. Montgomery Watt, Islam and Christianity Today: A Contribution to Dialogue,terj. Eno Syafrudien (Jakarta: Gaya Media Pratama, 1991), h. 7 


\section{c. Upaya Mewujudkan Harmonisasi Beragama}

Usaha-Usaha Dalam Mencapai Kerukunan Antar Umat Beragama Di bawah ini ada beberapa langkah penting dan strategis untuk memupuk jiwa toleransi beragama dan membudayakan hidup rukun antar umat beragama. Langkahlangkah berikut paling tidak akan meminimalkan konflik agama. Kiat-kiat itu adalah sebagai berikut.

1) Menonjolkan segi-segi persamaan dalam agama; tidak memperdebatkan segi-segi perbedaan dalam agama.

2) Melakukan kegiatan sosial yang melibatkan para pemeluk agama yang berbeda.

3) Mengubah orientasi pendidikan agama yang menekankan aspek sektoral fiqhiyah menjadi pendidikan agama yang berorientasi pada pengembangan aspek universal-rabbaniyah.

4) Meningkatkan pembinaan individu yang mengarah pada terbentuknya pribadi yang memiliki budi pekerti yang luhur dan akhlakul karimah.

5) Menghindari jauh-jauh sikap egoisme dalam beragama sehingga mengklaim diri yang paling benar.

Sementara itu, melihat kondisi kehidupan beragama sekarang ini, konflik anta rumat beragama, menjadi bagian yang tidak terpisahkan dari dinamika kehidupan berbangsa dan bernegara. Peristiwa-peristiwa seperti itu tidak hanya terjadi atas dasar perbedaan agama, tetapi juga terjadi antara orang atau kelompok-kelompok dengan agama yang sama, maka kerukunan yang perlu dibangun bukan hanya kerukunan antar agama, melainkan juga kerukunan antar orang atau kelompok dalam agama yang sama.

\section{Potret Harmonisasi Masyarakat Beragama di Wiyono Kabupaten Pesawaran}

Setelah data diperoleh, maka data tersebut dianalisa dengan menggunakan metode kualitatif.Metode kualitatif adalah data yang dapat diukur secara tidak langsung. Sehubungan dengan ini maka yang dimaksud dengan data kualitatif adalah suatu analisa yang didasarkan pada kasus-kasus, dan analisa tersebut akan memberikan suatu kesimpulan diambil dengan menggunakan metode berfikir 
induktif, metode induktif yaitu menarik suatu kesimpulan dari yang bersifat umum ke yang khusus.

Berdasarkan anilisa pada data yang telah dikumpulkan, maka dapat terlihat dengan jelas bahwa interaksi sosial yang terjadi di tengah-tengah masayarakat Wiyono kabupaten Pesawaran terjalin dengan baik; dengan kata lain terjadinya proses asosiatif. Secara terinci akan dipaparkan pada bagian berikut ini.

\section{a. Kerja sama}

Kerja sama merupakan bentuk interaksisosial yang utama.Tanpa adanya kerja sama, mustahil manusia mampu memenuhi kebutuhannya sendiri.Kerja sama yang terjadi pada masyarakat Wiyono adalah proses saling mendekati dan bekerja sama antarindividu, antara individudan kelompok, atau antarkelompok, dengan tujuan untuk memenuhi kepentingan dankebutuhan bersama.Kerja sama dapat kita temukan pada semua kelompok umur, mulai anak-anak sampaiorang dewasa. Pada hakikatnya, kerja samayang timbul pada masyarakat Wiyonio terjadi dengan kesadaran sosial:(1) orang menyadari bahwa mereka mempunyai kepentingankepentingan yang sama,(2) masing-masing pihak menyadari bahwa mereka hanya mungkin memenuhi kepentingan-kepentinga mereka tersebut melalui kerja sama.

b. Akomodasi

Akomodasi adalah usaha-usaha manusia untuk meredakan suatu pertentangan.Akomodasi dilakukan dengan tujuan tercapainya kestabilan dan keharmonisan dalamkehidupan.Akomodasi dalam masyarakat Woyono dilakukan dalam meminimalisir perbedaanperbedaan yang terjadi pada masyarakat, namun lebih mengedepankan persamaan-persamaan yang ada dalam kehidupan masyarakat; seperti persoalan kesulitan hidup atau kemiskinan yang banyak dialami oleh kebanyakan masyarakat, kondisi ini menjadi pintu tejalinnya kebersamaan dalam mengupayakan meningkatkan tarap kehdupan masyarakat di desa Wiyono.Artinya, Akomodasi merupakan bentuk penyelesaian tanpamengorbankan salah satu pihak.Adakalanya, pertentangan yang terjadi sulit diatasisehingga membutuhkan pihak ketiga sebagai perantara.Adapun tujuan akomodasi adalah untuk mengurangi pertentangan antara orang perorangan atau kelompok-kelompok masyarakat sebagai akibat 
perbedaan yang muncul dalam kehidupan.Memungkinkan terwujudnya kerja sama antara kelompok-kelompok sosial yanghidupnya terpisah sebagai akibat faktor-faktor sosial psikologis dan kebudayaan.

c. Asimilasi

Asimilasi merupakan bentuk proses sosial yang ditandai dengan adanya usaha-usahamengurangi perbedaan-perbedaan di antara orang-orang atau kelompok manusia.Mereka tidak lagi merasa sebagai kelompok yang berbeda sebab mereka lebihmengutamakan kepentingan dan tujuan yang akan dicapai bersama. Bila keduakelompok masyarakat telah mengadakan asimilasi, batas antara kedua kelompokmasyarakat itu dapat hilang dan keduanya berbaur menjadi satu kelompok.Pada masyarakat desa Wiyono berasimilasi dengan dengan lintas budaya dan agama melalui media wadah yang disebut dengan kelompok sosial "Wisma Yasa Manunggal" yang di dalamnya terdapat interaksi dari tiga agama yaitu, agama Islam, Kristen, Khatolik yang semua agama itu membuat konsensus untuk berupaya mengentaskan kemiskinan penduduk, sehingga batas-batas antara kelompok masyarakat tidak begitu jelas lagi terlihat satudengan lainnya. Proses asimilasi timbul bila terdapat hal-hal berikut.(1) Kelompok-kelompok manusia yang berbeda kebudayaannya.(2) Orang perorangan sebagai kelompok tadi saling bergaul secara langsungdan intensif untuk waktu lama.(3) Kebudayaan-kebudayaan dari kelompok-kelompok tersebut masing-masingberubah dan saling menyesuaikan diri.Proses asimilasi dapat berlangsung dengan mudah atau dapat juga dihambat.

\section{d. Pengaruh Interaksi Sosial Terhadap Harmonisasi Beragama}

Sedangkan pengaruh interaksi sosial yang terjadi sangat berpengaruh pada keharmonisan hubungan antar agama; yakni Islam, Katolik, dan Kristen.Kaharmonisan antar agama pada masyarakat desa Wiyono dapat dilihat dari kebersaman mereka dalam menangani persoalan-persoalan masyarakat, kemiskinan, gotong royong, membangun desa, memeriahkan kegiatan-kegiatan peringatanperingan hari-hari besar nasional (peringatan hari kemerdekaan RI, hari sumpah pemuda, hari pendidikan nasional dll) dengan berbagai kegiatan yang dirayakan secara bersama-sama.

e. Faktor-Faktor yang Mempengaruhi Interaksi Sosial Asosiatif 
Faktoryang dapat mempermudah terjadinya suatu proses asosiatif antara lain adalah sebagai berikut.(1) Toleransi(2) Kesempatan-kesempatan yang seimbang di bidang ekonomi(3) Sikap menghargai kehadiran kelompok lain dan kebudayaannya(4) Sikap terbuka dari golongan yang berkuasa dalam masyarakat(5) Memiliki persamaan historis dalam unsur-unsur.

\section{E. Penutup}

Dari paparan yang telah dikemukakan pada bagian-bagian terdahulu, maka disimpulkan hal-hal sebagai berikut:

a. Pola hubungan interaksi sosial yang bersifat asosiatif yang terjadi pada masyarakat desat Wiyono dapat tercipta karena adanya kerja sama, akomodasi dan asimilasi.

b. Pengaruh interaksi sosial yang terjadi pada masyarakat desa Wiyono sangat berpengaruh pada keharmonisan hubungan antar agama; yakni Islam, Katolik, dan Kristen.

c. Faktoryang dapat mempermudah terjadinya suatu proses asosiatif antara lain adalah sebagai berikut.(1) Toleransi(2) Kesempatan-kesempatan yang seimbang di bidang ekonomi(3) Sikap menghargai kehadiran kelompok lain dan kebudayaannya(4) Sikap terbuka dari golongan yang berkuasa dalam masyarakat(5) Memiliki persamaan historis dalam unsur-unsur 


\section{Daftar Pustaka}

A. Mukti Ali, "Agama, Moralitas dan Perkembangan Kontemporer" dalam Mukti Ali, dkk, Agama dalam Pergumulan Masyarakat Dunia (Yogyakarta: Tiara wacana: 1997).

A.A. Yewangoe, Agama dan Kerukunan ( Jakarta : PT Gunung Mulia, 2002).

Abdullah Ali, Agama dalam Ilmu Perbandingan Agama (Bandung : Nuansa Aulia,2007).

Abdulsyani, Sosiologi Skematika Teori, dan Terapan, (Jakarta: Bimi Aksara, 2012).

Agung Triharyanto \& Eko Sujatmiko, Kamus Sosiologi, (Surakarta: PT. Aksarra Sinergi Media, 2012).

Agus Ahmad Safei. Sosiologi Islam ; Transformasi Sosial Berbasis Taubid (Bandung : Simbiosa Rekatama Media, 2017).

Anis Malik Thoha, Tren Pluralisme Agama: Tinjauan Kritis, cet ke 2 ( Jakarta : Perspektif Kelompok Gama Insani, 2006).

Azyumardi Azra, Koneks Berteologi di Indonesi a: Pengalaman Islam (Jakarta: Paramadina, 1999).

Bernard Raho SVD, Agama Dalam Perspektif Sosiologi (Jakarta, Obor, 2012).

Burhan bungin, Analisis data Penelitian Kulitatif, (Jakarta: PT. Raja Grafindo Persada, 2010).

Metodologi Penelitian Kualitatif, (Jakarta: PT. Raja Grafindo Persada, 2001).

Cholid Narbuko dan Abu Achmadi, Metodologi Penelitian, (Jakarta: PT. Bumi Aksara, 2010).

Dadang Kahmad, Sosiologi Agama, (Bandung : PT. Remaja Rosdakarya, 2000).

Djam'an Satory \& Aan Komariyah, Metodologi Penelitian Kualitatif, Bandung, Alfabeta, 2009). 
Elizabrth K. Notingham, Agama dan Masyarakat, Suatu Pengantar Sosiologi Agama(Jakarta: PT Raja Grafindo Persada, 1996).

Fauzi Fatah. Solidaritas Sosial Keagamaan dalam Masyarakat Perkotaan (Bandar Lampung: IAIN Raden Intan Lampung, 1995).

J.B. Banawiratman dan Franz Magniz-Suseno, "Dinamika Kerukunan Umat Beragama Di Indonesia Tinjauan Kristen Katholik", dalam Mursyid Ali, Dinamika Kerukunan Hidup Beragama Menurut Perspektif Agama-Agama Bingkai Teologi KerukunanHidup Beragama (Jakarta: Badan Penelitian Pengembangan Agama Proyek PeningkatanKerukunan Hidup Umat Beragama, 2000).

J.B.A.F. Maijor Polak, Sosiologi: Suatu Buku Pengatntar Ringkas, (Jakarta: Ichtiar Baru - Van Hove, 1985).

J.Dwi Narwoko \& Bagong Suyanto, Sosiologi: Teks Pengantar dan Terapan, (Jakarta: Prenada Media Grup, 16).

Josef Van Ess, "Islam dan Barat dalam Dialog", dalam Nurcholish Madjid, dkk., Agama dan Dialog Antar peradaban (Jakarta: Paramadina, 1996).

Kartini Kartono, Metodologi Riset Sosial, ( Bandung: Mandar Maju), 1990).

Leonard Swidler, "The Dialogue Decalogue, Ground Rules for Interreligious Dialogue", dalam James H. Kroeger, M.M., Inter religious Dialogue (Davao City: tp, 1990).

Muhammad Basrowi \& Soenyono, Memahami Sosiologi, (Surabaya: Lutfansah Mediatama, 2004).

Muhammad Riva'i, Ilmu Perbandingan Agama ( Semarang : Wicaksana, 1984).

Mukti Ali, Metode Penelitian Agama Suatu Pengantar, (Yogjakarta: Tiara Wacana, 1998).

Noeng Muhadjir, Metodologi Penelitian Kulaitatif, (Yogyakarta: Rake sarasinP.O. Box 83, 1990).

Periantalo Jelpa. Penyusunan Skala Psikologi. (Pustaka Pelajar: Jakarta, 2015). 
Profil Desa Wiyono Kecamatan Gedongtataan Kabupaten Pesawaran, Tahun 2015.

R. Bintarto. Interaksi Desa Kota dan Permasalabannya (Jakarta : Ghalia Indonesia, 1929).

Sekretaris Negara RI, UUD 1945, GBHN dan P 4, (Jakarta : tt).

Soejono Soekanto, Sosiologi Suatu Pengantar (Jakarta: PT. RajaGrafido Persada, 2013).

Soetomo, masalah sosial dan upaya pemecahannya, (Jakarta: pustaka pelajar, 2010).

Sugiono, Metodologi Penelitian Pendidikan, (Bandung: Alfabeta, 2010).

Sugiono, Statistik Untuk Penelitian, ( Bandung: Alvabeta, 2015).

Sugiyono, Penelitian Kuantitatif Kualitatif dan R\&D. (Bandung : Alfabeta, 2009).

Suharsimi Arikunto, Prosedur Penelitian: Suatu Pendekatan Praktis, (Rineka Cipta: Jakarta).

Syeh Muhammad Abduh, Risalah Taubid(Jakarta: Bulan Bintang, 1979).

V. Wiratna Sujarweni,Metodologi Penelitin: Lengkap, Praktis, dan Mudah Dipahami, (Yogyakarta: PT. Pustaka Baru, 2014).

W. Montgomery Watt, Islam and Christianity Today: A Contribution to Dialogue,terj. Eno Syafrudien (Jakarta: Gaya Media Pratama, 1991).

Zainal Abidin dan Ahmad Safe'i. Sosiosophologi ; Sosiologi Islam Berbasis Hikmah(Bandung: CV Pustaka Setia, 2003).

Zainal Abidin dan Ahmad Safe'i. Sosiosophologi ; Sosiologi Islam Berbasis Hikmah(Bandung: CV Pustaka Setia, 2003). 